\title{
EDITORIAL
}

\section{Redescriptions Goes Open Access}

\author{
Tuija Pulkkinen \\ University of Helsinki, FI \\ tuija.pulkkinen@helsinki.fi
}

Keywords: Redescriptions; Open access; Hannah Arendt; performativity

With the publication of this issue of Redescriptions, we are happy to announce that within the period 2018-2019 Redescriptions has successfully completed a change of publishers to the new Helsinki University Press (HUP). With this relocation, Redescriptions becomes fully open access journal, with no costs to the readers or the authors.

This move is made in the spirit of Plan S, an open access political effort developed by Science Europe, initiated by a coalition of partners, and strongly supported by the EU. The key idea is to make publicly funded research completely open access, rather than being stuck behind paywalls. Open access to research is in the interest of researchers, research institutions, and research communities, but also decision makers, civil society and citizens. The research that has been funded by public money should have its results openly accessible by all. The role of publishers such as HUP, which provide their professional expertise in research publishing, is essential for keeping the quality of open research publishing high, while keeping the costs at reasonable level with public support through research funding institutions, libraries, and universities. The research publishing world is undergoing transformation, and Redescriptions is taking a bold step into this new world of publishing.

As a result of the exceptionally demanding time of change, in 2019, Redescriptions will publish only one issue, which is this one. The issue includes four articles and five book reviews. All three aspects of the characteristic multidisiciplinarity of the Redescriptions's unusual profile are present in this issue: the articles concern political thought, the history of concepts, and feminist theory.

In the first article, Stella Sandford explores the history and politics of classificatory concept of 'sex,' which is a crucial part of the conceptual history of interest to feminist theorizing. Sandford asks what kind of classificatory category is sex, and traces the use of the biological categorization of 'genus' as well as 'species' all the way back to Aristotle's logical and zoological categories. Sandford argues that in Aristotle, the difference between female and male is a difference based on common sense, and she then asks, provocatively, whether the same might be the case in the contemporary biological sciences, which continue to talk of the male and female 'forms' of different animals. Perhaps the category of 'sex' continues to be not actually a science-based category at all, but crucially based on common sense, also in contemporary biology.

From the point of view of the conceptual history of sex and gender vocabulary, Sandford points out interesting observations concerning the Aristotelian term 'genos.' Despite the frequent use of the word 'genos' in many other contexts of classification, Aristotle does not refer 
to males or females as a genos. 'Sex' was, however, later added into these texts as a category. As Sandford notes, twentieth-century translators of Aristotle's works on animals into English often make use of the English word 'sex,' and phrases such as 'sex difference' and 'the two sexes,' when translating Aristotle's claims about male and female animals. Within the history of the biological sciences, Sandford concludes, the category and term 'sex' is not self-evident, but indeed a historical and conceptual problem which requires further work.

The other three articles deal with the more conventional area of political thought, and although none of them makes a direct reference to Hannah Arendt, I would see all of them as connecting to performativity in politics in Arendtian terms. They all take up different aspects of Arendtian performatives: the performativity of constitution; the crucial aspect of stage and theatricality in public politics; and the performative power of speech in parliamentary debates.

Verena Frick's article engages with the results of a (re-)constitutive moment in post-war Germany and in particular, the constitutional court (FCC), which was established after 1949. She argues that democracy's guardianship role given to the FCC has also contributed to what she calls justicization of politics. In this special relationship between law and politics within German political practice and thought, politics is controlled by a substantial concept of constitutional rights as being the principle of political justice. Frick argues that the distrust of parliamentary politics involved in the practice shifts political power and competences to unelected, more expert driven, institutions.

Frick analyzes the historical coming into being of this distinctive German constitutionalism, based on a constitutional theory of integration in which the constitution was expected to unify society as a polity. She also looks closely at how the concept of values has entered into constitutional rhetoric, and critically points out that constitutional values not only impose guidelines on the legislator but might eventually be enforced constitutionally and therefore juridically against the legislator. All this, she argues, comes with costs to democracy. Frick points out that interwoven into the idea of value constitutionalism is a deep-rooted distrust in procedural democracy, as well as deep-rooted belief in the 'legal science' of the academic dogmatic reasoning of law, which she calls 'juridical epistocracy'.

Henk te Velde writes about 'theatre' in parliamentary politics and strongly defends the view that the 'theatrical side' of democracy needs attention. He shows that such theatricality is not a recent invention of Brexit times, but it has been a crucial aspect of modern parliaments since the French revolutionary parliaments after 1789 , where galleries were filled with up to two thousand spectators. Similarly, the critique directed towards politicians who perform for audiences is not just the product of modern media, but has been there since the time when parliaments were first opened to the public.

Henk te Velde concentrates on the role of melodrama in French and British parliaments during the nineteenth century, but also provides an interesting example of the "untheatrical' Dutch parliament, where politicians did not play to the gallery but wished to appear as dignified representatives of the people. However, he also notices that while in contemporary France and Britain populist movements have had trouble gaining a foothold within parliament, in the Netherlands this has not been the case. Te Velde concludes that parliaments have always been not just institutions but also to a certain extent a modern version of the agora, open to the public, albeit with an important dignified aspect, and that these two sides both need to be taken seriously. Only by acknowledging the 'theatrical' side of parliaments can we fully appreciate both the ambiguity and the crucial importance of the public nature of parliaments.

In the final article, Anna Kronlund provides an example of parliamentary performativity through focusing on how parliament performs its power in its relation to the constitution. 
Her example is from the US Congress debates on war powers, and she looks closely at the congressional debate in regard to authorization of using US armed forces against Iraq in 2002. It is generally acknowledged that the consultative and decisive roles of the US Congress have to some extent collapsed vis-à-vis war-making, while the powers of the executive branch have been strengthened. Kronlund focuses on the actual discussions in this case and claims that something happens in the course of this performance: that the Congress does not give away its powers but rather adapts its power to the changing conditions.

Kronlund claims that it is relevant to examine debates on war powers in the U.S. Congress, because reformulations of congressional powers takes place within them. Her point is that the debates on war powers are inherently political in the sense that each of these debates, including the one that she examines, can be considered to provide momentum for Congress to address its constitutional powers. In these debates, positions can change, new interpretations are formulated, and changing circumstances and power relations are addressed. In other words, Kronlund treats the debates as being performative with respect to the very power of the political institution.

\section{Competing Interests}

The author has no competing interests to declare.

How to cite this article: Pulkkinen, Tuija. 2019. "Redescriptions Goes Open Access." Redescriptions: Political Thought, Conceptual History and Feminist Theory 22(1): 1-3. DOl: https://doi.org/10.33134/ rds.315

Submitted: 07 November 2019 Accepted: 07 November 2019 Published: 03 December 2019

Copyright: (c) 2019 The Author(s). This is an open-access article distributed under the terms of the Creative Commons Attribution 4.0 International License (CC-BY 4.0), which permits unrestricted use, distribution, and reproduction in any medium, provided the original author and source are credited. See http://creativecommons.org/licenses/by/4.0/.

HUP Redescriptions: Political Thought, Conceptual History and

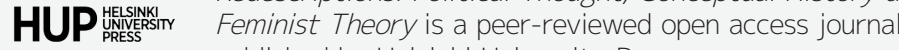
published by Helsinki University Press. 